\title{
Public Views of the Economy of the Renewable Energy Sources: Evidence from Russia
}

Dalia Streimikiene ${ }^{1}$ and Victoria Akberdina ${ }^{2}$

ABSTRACT

\begin{abstract}
Recent worldwide growing awareness of the global climate changes stressed the importance of developing and supporting the renewable energy sources (RES). However, the public support for RES varies across various countries and regions, especially those abundant in traditional fossil fuels. This paper presents the analysis of the public views of the economics of the renewable energy using the results of the online survey $(N=750)$ conducted in several regions of the Russian Federation, a country abundant in natural gas and oil. Our results indicate that there is a mixed opinion on trust in RES as opposed to the traditional energy sources. Even though we found some support for the renewable energy technologies, it appears that it is correlated with the respondents' concerns about the environmental protection and sustainable development as well as with some demographic variables. The outcomes of the regression analysis confirmed that positive attitudes towards climate protection predetermined the support for various types of RES, while the financial or political gains did not come through as significant. The results indicate that public views on the renewable energy sources could and should be shaped by the information campaigns and presentations in mass media conducted by relevant policymakers and public authorities.
\end{abstract}

KEY WORDS: Renewable energy, fossil fuels, public opinion, energy policy, energy economics, Russia.

JEL Classification: H30, P18, Q20, Q30.

'Lithuanian Institute of Agrarian Economics, Vilnius, Lithuania

${ }^{2}$ Institute of Economics of the Urals Branch of the Russian Academy of Sciences, Yekaterinburg, Russian Federation

\section{Introduction}

The use of clean, renewable energy is one of the most important measures the humanity can take to reduce its impact on the environment while maintaining its economic growth and well-being. Many countries and regions, including the European Union (EU), heavily committed to shifting towards the renewable energy sources (RES) by substituting the obsolete fossil fuels that pollute the environment (Liobikiene \& Butkus, 2017; Newbery et al., 2018; Brodny \& Tutak, 2020). However, with regard

Correspondence concerning this article should be addressed to: Dalia Streimikiene, Lithuanian Institute of Agrarian Economics, Vilnius, Lithuania.

E-mail: dalia@mail.lei.lt to the above, one has to remember that electricity generation is responsible for more greenhouse gas emissions than all car and flight movements combined (Tagliapietra et al., 2019). Clean energy also reduces the impact of coal mining and gas extraction. Renewable energy is becoming a real valueadded system, combining the ecological need to mitigate climate change with society's vision of economic opportunity (Nathaniel \& Khan, 2020). Replacing fossil fuel infrastructure requires a combination of renewable energy, energy efficiency, and energy storage. Energy efficiency is one of the most important measures to reduce the impact of climate change and to create a sustainable energy future (Nowotny et al., 2018). Another opportunity is lo- 
cal value creation, based on timely improvement of energy access, reduction of resource conflicts in the water-limited world and improvement of air quality for a healthier environment (Aklin et al., 2017; Chen et al., 2020). More and more countries are becoming aware of these multiple opportunities and introduce changes to their energy policies to reflect these social benefits by actively pursuing and shaping a new energy world based on renewable energy (Al-Marri et al., 2018; Clausen \& Rudolph, 2020). With global emissions rising, increased electrification and the expansion of renewable energy could make the difference that ensures that we meet future climate targets. New findings from the International Renewable Energy Agency (IRENA) underscore the importance of expanding efforts to switch from fossil fuels to renewable energy (IRENA, 2017). In view of the increasing development and demand for energy worldwide, there is an urgent need for clean renewable energies, which play the main role in the generation of electricity and the future smart grids.

Renewable energy sources include wind, solar, hydrothermal, geothermal, biomass, biofuel, and hydropower, as well as solar and wind energy. As a renewable energy source, offshore wind, for example, has a significant impact on the cost of fossil fuels when based on conventional power generation (Park \& Kim, 2019). The cost of offshore wind projects has fallen in recent years, opening up a new opportunity for large-scale clean energy production. The development of large-scale offshore wind energy can generate as much energy as the burning of fossil fuels at a lower cost than conventional wind turbines. Renewable energy is therefore an energy derived from natural resources that are replenished over a period of time without exhausting the earth's resources. The production of energy from non-renewable resources takes a heavy toll on the environment and pollutes air, land and water. It is possible to generate electricity from renewable energy sources without producing carbon dioxide ( $\mathrm{CO} 2)$, the main cause of climate change and an important factor in global warming (Skytt et al., 2020). These resources also have abundant capacity, which is almost everywhere on this planet.
With regard to the above, many government policies that require a certain share of a state's electricity to come from renewable sources provide significant benefits in terms of energy security, energy efficiency, and environmental sustainability (Lisin et al., 2019; Elavarasan et al., 2020). Renewable energy offers an alternative to fossil fuels such as coal, oil, and natural gas, which contribute to climate protection. Renewable energy sources might secure almost 200000 jobs, improve air quality and reduce greenhouse gas emissions by over 2.5 million tons of $\mathrm{CO} 2$ per year in the United State alone (National Renewable Energy Laboratory [NREL], 2016). It is assumed that $50 \%$ of the world's energy supply will be generated from renewable energy sources by 2030 (Laslett et al., 2017; Dudin et al., 2019). The size of renewable energy sources is due to their low cost, high efficiency and low carbon footprint. They might also reduce poverty for poor people, who rely largely on natural resources. Renewable energy sources will be important not only for minimizing pollution, but also for boosting economies, energy security and employment opportunities (Balitskiy et al., 2014). This is because many countries have abundant renewable energy sources and also show the potential to close the gap in energy demand. Renewable technologies are considered a clean energy source and their optimal use is sustainable based on current and future economic and social needs. It produces a minimum of secondary waste, reduces environmental pollution, and minimizes greenhouse gas emissions. The dependence on fossil fuels for its energy needs has hampered the development of renewable technologies such as wind, solar, and geothermal. Renewable energy sources are natural and permanent energy flows that take place in the immediate vicinity. Hydropower is an essential energy source that uses water flowing from high to low altitudes, primarily to rotate turbines and generate electricity. These include wind, solar, geothermal, hydroelectric, and hydroelectric power plants. These energy sources have no impact on the environment, but fossil fuels do. Fossil fuels are dumped into the atmosphere to generate electricity, polluting air and water. In total, 1.2 billion tons of fossil fuels were generated from electricity generation in 2014, which is about 2.5 per cent of global emissions (Triglobal, 2020). 
However, public views on the renewable energy sources are not always plausible and positive. People tend to be afraid of innovations and new technologies. Traditional dependence of the fossil fuels that provide cheap and affordable energy (even though they also pollute the atmosphere and generate vast amounts of $\mathrm{CO} 2$ ) became a habit that is difficult to change overnight. In addition, there are many countries with economies heavily dependent on fossil fuels extraction and sales, such as, for example, Gulf States, Iran, Venezuela, or Russian Federation. Shifting towards the renewable energy might be met with dislike and negative attitudes.

In this paper, we are focusing on determining the public views of the renewable energy using the example of the country abundant in fossil fuels represented by the Russian Federation. The country represents an interesting case that is worth investigating and analyzing in order to generate relevant policy implications and recommendations for the stakeholders and policy-makers in the field of energy economic policies.

\section{Literature Review}

Generally, renewable energy industries already employ millions of people, are cheaper than alternatives to fossil fuels and reduces negative environmental impacts which has been noted in the case studies from numerous countries (Zhang et al., 2017; Lisin et al., 2018; Dell'Anna, 2020). Given the clear economic and environmental benefits of renewable energy, they are an excellent opportunity for us to close the political gap. However, one needs to minimize the gap between public opinion and the elected officials (Ntanos et al., 2018).

One can see that the renewable energies are developing into a real added-value system that combines ecological necessity and climate protection with society's vision of economic opportunities (Zerrahn et al., 2018; Aslanturk \& Kiprizli, 2020). Local value creation based on timely access to energy, reducing resource conflicts in our water-scarce world, and improving air quality for a healthier environment are among these opportunities. More and more countries are recognizing these multiple opportunities and changing their policies to take these social benefits into account, while actively pursuing and shaping a new energy world based on renewable energy (Setyowati, 2021). Driven by impressive technological innovation and cost reductions, renewables are viewed in a growing number of countries as a viable alternative to fossil fuels as an alternative source of energy for the future, strengthened by their low energy costs and low environmental impact (Guild, 2019). These benefits include the ability to respond to growing energy needs and reduce the increased water demand caused by fossil-fuel power generation. By enabling decentralized power generation, the rapidly expanding world of renewable energy has opened up business models for many economic agents, including local communities, citizens, and civic cooperatives (Brown et al., 2019). In order to reap the social benefits of renewable energy, national energy policies can create an environment that allows the efficient development of wind, solar and other renewable energy sources (Tiba \& Belaid, 2021). Social and political movements must accompany the promotion of sustainable energy development in order to achieve energy policy objectives and contribute to defined climate objectives such as mitigation and adaptation to climate change. For example, the decentralization of wind turbines led to a frequently observed process in which wind turbine advocates and opponents diverge in perceptions of wind turbines (Avila, 2018). These results allow researchers to focus on the previously published studies to compare cases with acceptance patterns, while field studies have been used directly to cover a wide range of renewable energy sources such as wind, solar, and hydropower. With regard to economic measures, many authors suggested that social acceptance of wind energy can be improved through public education and procedural planning measures (Suškevičs et al., 2019). For some people, the economic benefits outweigh the environmental and social costs. For example, education information can indirectly be a starting point for improving procedural planning measures to improve social acceptance. The economic benefits of RES also seem to act as monetary compensation, 
outweighing the perceived negative effects of the environmental and social costs of renewable energy (Bartczak et al., 2017). Given the predicted impact of climate change and the increasing number of renewable energy sources, the social benefits of renewable energy could become all the more important in the coming decades. The real game change is the emergence of new energy companies in countries like Germany and Denmark. As a result, renewable energy in these countries enjoys broad financial ownership that drives their markets and distributes economic gains to society (Tschopp et al., 2020). Unlike established energy companies and their dominant business models, these new players are able to take advantage of the economic opportunities that arise from renewable energy. Since the collapse of oil prices in the late 1980s, interest in renewable energy, such as wind and solar, which faced significant technical and cost constraints, has declined, while other renewables, such as hydropower and biomass, continue to grow (Itta \& Tiawon, 2020). Rising price volatility and dependence on fossil fuels in developing countries rekindled governments' interest in ensuring energy security. New concerns, unknown before the previous oil crisis, have reinforced the growing contribution of renewable energy as an energy source to the global economy.

Traditional energy industries die hard. For example, in the United States, Donald Trump's administration has thrown a lifeline to the battered coal industry by easing restrictions on coal-fired power plants. The Energy Information Administration expects that it will not reverse the decline in coal production and that its share of electricity generation will be below $22 \%$ by 2021 (Zeballos-Roig \& Wang, 2019). The Trump administration, however, relaxed environmental regulations and wanted to open more public land to drilling. Insider surveys support the notion that the public is using more renewable energy sources while continuing to rely on fossil fuels that pollute the atmosphere and contribute to climate change (Qazi et al., 2019). After the U.S. Federal government withdrew its efforts to combat climate change under the Trump administration, states and cities filled the void, taking this in the direction favored by the public: reducing emissions and developing clean energy sources (Cooper, 2018). Renewable energy was supported by conservatives who oppose the scientific consensus on climate change. At the same time, moderate liberals, who agree in principle with the need to reduce greenhouse gases, rejected the local environmental impact that development such as wind farms or solar parks might have.

All in all, the expansion of low-carbon renewable energy remains an essential step in climate protection, but is motivated by other arguments that require more local effort and public engagement, as climate change advocates are generally well aware (Hamilton et al., 2019). This debate, coupled with long-standing economic pressure to reduce other countries $\$$ dependence on energy, has drawn attention to the importance of renewable forms of energy, including solar and wind. Public opinion on energy issues is generally in favor of developing renewable energy sources such as wind and solar when it comes to their use (Bayulgen \& Benegal, 2019). Strong majorities of all parties, ideologies, and groups favor more solar or wind power, while there is little support for expanding fossil fuels or nuclear power. In many cases, energy from renewable sources is already cheaper than that from non-renewable sources, and energy prices remain stable. Since energy prices cover all the above-mentioned renewable energy issues, they should stabilize the economy, which in turn will keep prices stable for consumers and businesses.

When it comes to the Russian Federation, one would probably agree with us that the wide availability of oil, gas and coal that stifled the development of renewable energy. Nevertheless, the tide is changing. Recently, Russia set a target of increasing its share of renewable energy to $4.9 \%$ by 2030, and should increase that share from 3.2\% to four times that of the US and the EU (Proskuryakova \& Ermolenko, 2019; Mitrova \& Melnikov, 2019). In 2013, a governmental decree was adapted setting up an ambitious plan to increase the capacity of Russian wind and solar power generation to 5.9 GW by the end of 2024. This is quite possible due to the developed energy infrastructure in the 
country (Konova et al., 2012; Zlyvko et al., 2014). In spite of its dependence on fossil fuels, Russia has excellent conditions for the development of renewable energy: a vast and scarcely populated territory with plenty of space suitable for solar, wind, and hydro power generation, strong and well-developed power network, experienced energy professionals with good skills and the determination to develop these sources of energy. However, it still remains a question whether the general public in Russia would accept these goals and embrace the renewable energy technologies. It is therefore worth trying to analyze this issue in further depth.

\section{Research Methodology}

The major purpose of our research methodology was to outline the methods and strategies that were employed during data collection and analysis. Our research focused on the quantitative data collection that was based on administering the online questionnaires. The research was conducted in accordance with similar surveys and research projects in other countries such as, for example, India, Ireland, Israel, or the Czech Republic or (Rausser et al., 2018; Aklin et al., 20181 Čábelková et al., 2020b, Čábelková et al., 2020b; or DiPersio et al., 2021). The questionnaires were designed to obtain relevant information and people's opinions on the renewable energy in Russia.

In course of collecting our data using the online questionnaires, we stumbled upon some detectable uncertainty: a considerable part of the respondents said they were "not sure" whether or not they supported the renewable energy policy. It appears that the public is more likely to support direct or in direct measures to promote renewable energy than direct measures to counter it. Similarly, the situation is uncertain with higher rates of supply required for the use of energy from non-renewable sources. However, we can also conclude that the public is not particularly concerned about the direct or individual costs of this policy, such as the cost of using non-renewable energy sources or the impact on the economy

This study was conducted with a reliable and statistically significant sample of a total of 750 respondents from the four districts of the Russian Federation (Central, Southern, Volga, and Ural districts). Our sampling was based on a representative sampling with quotes (geographical location, age, gender, as well as education). In general, our sample appears to be a representative one for the Russian Federation and can be used for the statistical analysis and deriving valuable results and relevant policy implications. The descriptive statistics of the respondents is presented in Table 1 that follows in the next section.

The survey was conducted online with the help of local teams based in the universities and HEIs located in each of the four regions. The respondents were offered to answer both the socio-demographic question as well as the questions mapping their attitudes towards the principle of sustainability, energy conservation and the climate change. Subsequently, the respondents were offered to reflect their opinions and rank their priorities for supporting (increasing) or not supporting (reducing) the on the six selected traditional and renewable energy sources (solar, wind power, natural gas, oil, coal, and hydro) alongside with expressing a neutral opinion about them (keeping the same). In total, about 1140 surveys were collected and processed, however only 750 surveys passed the validity test and were chosen for the analysis.

\section{Data Analysis}

The online survey was comprised of a series of carefully designed questions that helped to achieve the goal of our research study. The respondents to whom the online surveys were administered to included 390 males (52\%) and 360 females (48\%), making it a total of 750 participants. In this paper, frequency percentages were presented using statistical tables. A statistical program was used for tabulation, open space classification, and the running the regression analysis.

Figure 1 that follows reports the support declared by the respondents for the six presented renewable and traditional energy technologies represented by solar power, wind power, natural gas, oil, coal, and hydro energy. The responses were carefully recorded and analyzed. Overall, it appears that the energy technology with the greatest potential for increasing and developing is the solar power which is followed by the wind power. Additionally, one can see a large support for keeping the same share of Russian traditional energy industries represented by oil and gas. It might be that 
Table 1

Descriptive Statistics of the Respondents and Online Survey Questions ( $N=750)$

\begin{tabular}{|c|c|c|}
\hline Variable & Response category & Value \\
\hline Gender & Male (1); Female (0) & 390 males (52\%); 360 females ( $48 \%)$ \\
\hline Age & Year of birth (subtracted from 2020) & 40.3 (mean) \\
\hline Education & Highest level of education & $60 \%$ with a tertiary degree ( $25-34$ years) \\
\hline Environmental concerns & Protection of the environment as a priority & $82 \%(615)$ \\
\hline $\begin{array}{l}\text { Economic priority: tradi- } \\
\text { tional energy sources }\end{array}$ & Likert scale-type questions & $\begin{array}{l}\text { not important }(20 \%) \text {; slightly important } \\
(12 \%) \text {; neutral }(30 \%) \text { important }(23 \%) \\
\text { very important }(15 \%)\end{array}$ \\
\hline $\begin{array}{l}\text { Economic priority: renew- } \\
\text { able energy sources }\end{array}$ & Likert scale-type questions & $\begin{array}{l}\text { not important (10\%); slightly important } \\
(6 \%) \text {; neutral (14\%) important (48\%) very } \\
\text { important ( } 22 \%)\end{array}$ \\
\hline
\end{tabular}

\section{Figure 1}

Respondents' Support for the Six Renewable and Traditional Energy Sources

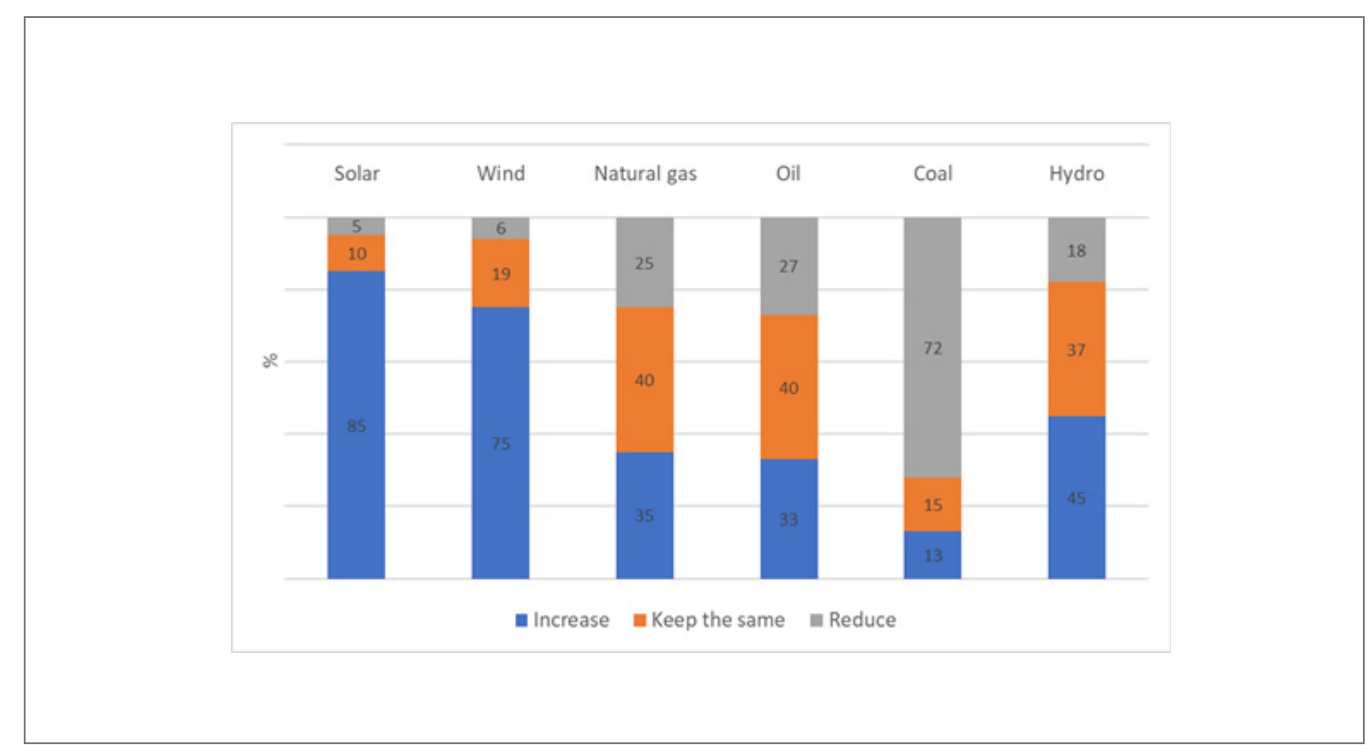


Table 2

Ordered Logistic Regressions Showing the Support for the Energy Sources

\begin{tabular}{lcccccc}
\hline Variable & Solar & Wind & Natural gas & Oil & Coal & Hydro \\
\hline Gender & $0.976^{* * *}$ & $0.837^{*}$ & $1.845^{* * *}$ & $3.250^{* * *}$ & 0.755 & $1.247^{* *}$ \\
Age & 1.105 & 1.116 & 1.132 & $1.109^{* * *}$ & 1.105 & 1.003 \\
Education & $2.478^{* * *}$ & $1.387^{* *}$ & $0.898^{* *}$ & 1.370 & $0.589^{* * *}$ & $0.922^{* * *}$ \\
Priority TES & 0.300 & $0.168^{\star *}$ & 1.879 & $1.997^{\star * *}$ & $3.396^{* * *}$ & 1.135 \\
Priority RES & $1.519^{* * *}$ & 1.169 & 0.929 & 0.771 & 0.858 & $1.080^{* *}$ \\
AIC & 981 & 1331 & 2649 & 2710 & 1594 & 2783 \\
BIC & 992 & 1326 & 2664 & 2721 & 1505 & 2894 \\
\hline
\end{tabular}

Note: ${ }^{\star} \mathrm{p}<0.05 ;{ }^{\star *} \mathrm{p}<0.01 ;{ }^{* \star} \mathrm{p}<0.001$

many people are not ready to let go of the profit-generating technologies that supplied Russian economy with cash for decades - it might take some time for many people to process that the shift towards RES is necessary (and that it might be even beneficial for the Russian economy) and to accept the new reality.

Table 2 that follows, reports the results of the ordered logistic regressions yielding the respondents' support of the traditional and renewable energy sources (three traditional and three renewable) with regard to their gender, age, level of education, and their declared priorities towards developing or reducing traditional and/ or renewable energy sources.

Based on outcomes reported in the Figure 1 and Table 2, it evident that a large number of respondents stress the need to promote the renewable energy sources in Russia. This is an interesting result given Russian dependency of the traditional fossil fuels for several decades. However, it is apparent that Russian citizens are also aware of the global climate changes and the necessity to search for the new alternative sources of energy.

When it comes to gender variable, it turns out that gender had considerable effect on the support for renewable energy. This is quite obvious since younger people nowadays are keen on supporting sustainable development and environmental protection, quite often thanks to the sustainable education in schools and universities.

As for the age of the respondents, it had the odds ratios close to 1 which yields little practical significance.

Furthermore, the level of education appeared to significantly predetermine the support for all energy types. This is quite understandable, since more educated people (tertiary education and higher) are more aware of the environmental and energy issues that are widely discussed in mass media and at all levels of the society.

The variables labelled as "Priority TES" (priority for the traditional energy sources) and "Priority RES" (priority for RES) came through as statistically significant in all respective models. The respondents who attributed greater value to the sustainable development and environmental protection tended to be the supporters of renewable energy and its further promotion.

The measures of the model relative quality represented by AIC and BIC indicate which models have a better fit. It becomes quite clear and apparent from our results that the models describing the best-known sources of renewable energy represented by the solar and wind power are the most representative and descriptive.

\section{Discussion of Results}

All in all, it seems that the public preferences for the role of energy policy in the development and implementation of energy policy cover a wide range of factors such as age, gender, race, level of education, economic status and political affiliation. This raises the question of how relevant it is to publish a scenario that focuses on the social aspects of energy policy, and not only those that can be quantified by the "techno-economic" aspect. If it was indeed social factors that determined the public's preference for a transition from fossil fuels to renewable energy, it raises questions 
about whether this is actually a social factor or not. More than half of our respondents from four Russian regions think that these scenarios could enable an enlightened energy discourse if the meaningful and reliable action strands created by non-experts to shape our energy future are missing. Based on the findings presented in this study, we argue that it is worth investigating the role of social factors in the development of model-based energy scenarios. Since scenario products can be distorted and simplified if shared with the lay community of experts, future research should use discourse analyses to identify relevant promises and concerns in energy debates. Today, it is not clear whether scenario projections in general are actually influenced by social factors, such as expectations of the status quo, or whether scenarios fundamentally analyze expectations that are deeply rooted in society and thus in the scenario makers. The expectation that the status quo will continue well into the future could correspond to self-assessed knowledge of the current state of energy production and consumption and expectations for future energy policy. The rationality of this is defined by the expectation that there will be a wealth of different energy sources in the future. Interestingly, it appears that the switch to renewable energy sources will not only be more efficient than fossil fuels, but will also occur without a sharp increase in fossil fuel prices. We do not claim here that these expectations are in line with expert opinion on the energy future, but the future energy system is likely to rely more heavily on renewable energy sources such as wind, solar, or hydro power. To achieve a sustainable energy transition, we need to examine a number of sustainable energy behaviors in a way that integrates public opinion and public policy, as well as expert research and policy recommendations. Firstly, we need to understand whether individual households are prepared to accept and use different renewable energy sources. To increase the efficiency of sustainable energy systems and to meet the energy needs of individuals and households around the world, the overall energy demand must be reduced. One way to reduce this problem may be to promote a sustainable oil and gas turnaround and an energy transition towards a more efficient energy system. An important question is whether this kind of knowledge can change the perceived effectiveness of public involvement in various renewable energy sources such as wind and solar. In this respect, it is important to examine the factors that determine public preferences for energy policy and its role in the transition to a more efficient energy system. The sustainable energy transition will bring about changes in the energy system and will require the implementation of different energy policies. The assessment of energy technology and policy is therefore determined by the underlying conceptualization of the transition from fossil fuels to renewable energy sources and thus by the public's preference for energy policy. The interaction between the public and energy scenarios is not subject to scrutiny by experts in energy modelling. Nevertheless, the results of this study suggest that scenarios derived from promises and concerns and disseminated by the media and political discussions do not provide an accurate representation of public energy and the associated expectations. Accordingly, both the promise and the concern depend on public preferences for energy policy and public expectations for the future. There appear to be a strong correlation between public expectations in the energy sector and formalized expert forecasts for the future. Social scientists know how to motivate and empower people to actively contribute toa sustainable energy transition. This includes not only combating anthropogenic climate change, but also changing perceptions, preferences and behaviors. There is a strong correlation between the energy and technology policy preferences of each cluster and the public's expectations of the energy sector.

\section{Conclusions and Implications}

Overall, one can see that the public views of the economy of the renewable energy sources is changing all around the world as a reaction to the global warming and climate change. It is now clear to everyone, including the policymakers and the members of the general public that situation is critical and some steps for mitigating these issues should be taken. Russian Federation is not an exception from this trend. Even though the country was and still is a major exporter of fossil fuels, it has now stepped on a path of developing alternative renewable energy sources similar to other world's major economies. Russian citizens tend to understand it and seem to start coping with the idea that the country has the potential for promoting RES. The results of this research confirm this trend and show 
that the public awareness of the importance of renewable energy is slowly but gradually changing in Russia into the direction of support of RES as the new reliable and sustainable energy source.

\section{Limitation and Future Research}

Speaking about the limitation of our research, several issues come to mind. First of all, when investigating the acceptance of renewable energy sources and their superiority over the traditional ones, one should add nuclear power (this is especially relevant in case of Russia). Nuclear power is both regarded as clean and safe and as dangerous (especially after Chernobyl and Fukushima disasters). It might be interesting to include it into the analysis for a broader picture.

Second, the study of such scope and magnitude meant certain difficulties for the interviewers and the respondents. Some of the surveys were not filled properly due to simple and redundant mistakes by the interviewers and the interviewees or were incomplete. In the future, it might be better to improve the sampling and online data collection techniques using some verification methods (e.g., a 2-factor verification), or perhaps providing the incentives to the respondents in order to keep them filling in surveys for longer periods of time in order to increase their validity and completeness.

Third, the study which would include the willingnessto-pay (WTP) or the willingness-to-accept (WTA) of the renewable energy technologies might be more insightful for determining the public acceptance of RES in Russian economy. Thence, it appears that this approach might also be used as a complimentary one to our research method presented in this study.

\section{References}

Aklin, M., Bayer, P., Harish, S. P., \& Urpelainen,

J. (2017). Does basic energy access generate socioeconomic benefits? A field experiment with off-grid solar power in India. Science Advances, 3(5), el602153. https://doi.org/10.1126/ sciadv. 1602153

Aklin, M., Cheng, C. Y., \& Urpelainen, J. (2018). Social acceptance of new energy technology in developing countries: A framing experiment in rural India. Energy Policy, 113, 466-477. https:// doi.org/10.1016/j.enpol.2017.10.059

Al-Marri, W., Al-Habaibeh, A., \& Watkins, M. (2018). An investigation into domestic energy consumption behaviour and public awareness of renewable energy in Qatar. Sustainable Cities and Society, 41, 639-646. https://doi.org/10.1016/j. scs.2018.06.024

Aslanturk, O., \& Kiprizli, G. (2020). The role of renewable energy in ensuring energy security of supply and reducing energy-related import. International Journal of Energy Economics and Policy, 10(2), 354-359. https://doi.org/10.32479/ ijeep. 8414

Avila, S. (2018). Environmental justice and the expanding geography of wind power conflicts. Sustainability Science, 13(3), 599-616.

https://doi.org/10.1007/s11625-018-0547-4

Balitskiy, S., Bilan, Y., \& Strielkowski, W. (2014). Energy security and economic growth in the European Union. Journal of Security \& Sustainability Issues, 4(2), 125-132. https://doi.org/10.9770/ jssi.2014.4.2(2)

Bartczak, A., Chilton, S., Czajkowski, M., \& Meyerhoff, J. (2017). Gain and loss of money in a choice experiment. The impact of financial loss aversion and risk preferences on willingness to pay to avoid renewable energy externalities. Energy Economics, 65, 326-333. https://doi.org/10.1016/j. eneco.2017.04.020

Bayulgen, O., \& Benegal, S. (2019). Green Priorities: How economic frames affect perceptions of renewable energy in the United States. Energy Research \& Social Science, 47, 28-36. https://doi. org/10.1016/j.erss.2018.08.017

Brodny, J., \& Tutak, M. (2020). Analyzing similarities between the European Union countries in terms of the structure and volume of energy production from renewable energy sources. Energies, 13(4), 913. https://doi.org/10.3390/en13040913

Brown, D., Hall, S., \& Davis, M. E. (2019). Prosumers in the post subsidy era: an exploration of new prosumer business models in the UK. Energy Policy, 135, 110984. https://doi.org/10.1016/j. enpol.2019.110984

Čábelková, I., Strielkowski, W., Firsova, I., \& Korovushkina, M. (2020a). Public Acceptance of Renewable Energy Sources: a Case Study from the Czech Republic. Energies, 13(7), 1742. https://doi. org/10.3390/en13071742

Č́belková, I., Strielkowski, W., Streimikiene, D., Cavallaro, F., \& Streimikis, J. (2020b). The social acceptance of nuclear fusion for decision making towards carbon free circular economy: Evidence from Czech Republic. Technological Forecasting and Social Change, 120477. https://doi. 
org/10.1016/j.techfore.2020.120477

Chen, Z., Li, P., Jiang, S., Chen, H., Wang, J., \& Cao, C. (2020). Evaluation of resource and energy utilization, environmental and economic benefits of rice water-saving irrigation technologies in a rice-wheat rotation system. Science of The Total Environment, 143748. https://doi.org/10.1016/j. scitotenv.2020.143748

Clausen, L. T., \& Rudolph, D. (2020). Renewable energy for sustainable rural development: Synergies and mismatches. Energy Policy, 138, 111289. https:// doi.org/10.1016/j.enpol.2020.111289

Cooper, M. (2018). Governing the global climate commons: The political economy of state and local action, after the US flip-flop on the Paris Agreement. Energy Policy, 118, 440-454. https:// doi.org/10.1016/i.enpol.2018.03.037

Dell'Anna, F. (2020). Green jobs and energy efficiency as strategies for economic growth and the reduction of environmental impacts. Energy Policy, 112031. https://doi.org/10.1016/j.enpol.2020.112031

DiPersio, T., Liedtke, N., Rosenthal, A., Wallace, A., Morris, A., Bar-On, I., \& Abu Hamed, T. (2021). Photovoltaic technology in Southern Arava of Israel: an analysis of public acceptance. International Journal of Sustainable Energy, 40(1), 85-103. https://doi.org/10.1080/14786451.2020.1 794865

Dudin, M. N., Frolova, E. E., Protopopova, O. V., Mamedov, O., \& Odintsov, S. V. (2019). Study of innovative technologies in the energy industry: nontraditional and renewable energy sources. Entrepreneurship and Sustainability Issues, 6(4), 1704-1713. http://doi.org/10.9770/ jesi.2019.6.4(11)

Elavarasan, R. M., Afridhis, S., Vijayaraghavan, R. R., Subramaniam, U., \& Nurunnabi, M. (2020). SWOT analysis: A framework for comprehensive evaluation of drivers and barriers for renewable energy development in significant countries. Energy Reports, 6, 1838-1864. https://doi. org/10.1016/j.egyr.2020.07.007

Guild, J. (2019). Feed-in-tariffs and the politics of renewable energy in Indonesia and the Philippines. Asia \& the Pacific Policy Studies, 6(3), 417-431. https://doi.org/10.1002/app5.288

Hamilton, L. C., Hartter, J., \& Bell, E. (2019). Generation gaps in US public opinion on renewable energy and climate change. PloS ONE, 14(7), e0217608. https://doi.org/10.1371/journal.pone.0217608

International Renewable Energy Agency [IRENA] (2017). Perspectives for the energy transition.
https://www.irena.org/-/media/Files/IRENA/ Agency/Publication/2017/Mar/Perspectives_for_ the_Energy_Transition_2017.pdf

Itta, I., \& Tiawon, H. (2020). Oil price shocks: Energy patterns and macroeconomic results in Indonesia. Contemporary Economics, 14(4), 444-452. https:// doi.org/10.5709/ce.1897-9254.417

Konova, O., Komarov, I., Lisin, E. (2012). The relevance of power generating capacities based on the combined cycle power plants of high power. Czech Journal of Social Sciences, Business and Economics, 1(1), 101-109. https://doi.org/10.24984/ cjssbe.2012.1.1.11

Laslett, D., Carter, C., Creagh, C., \& Jennings, P. (2017). A large-scale renewable electricity supply system by 2030: Solar, wind, energy efficiency, storage and inertia for the South West Interconnected System (SWIS) in Western Australia. Renewable Energy, 113, 713-731. https://doi.org/10.1016/j. renene.2017.06.023

Liobikiené, G., \& Butkus, M. (2017). The European Union possibilities to achieve targets of Europe 2020 and Paris agreement climate policy. Renewable Energy, 106, 298-309. https://doi. org/10.1016/j.renene.2017.01.036

Lisin, E., Rogalev, N., \& Okley, P. (2003). The impact model of the production capacities structure of the energy system and the regional energy security. Terra Economicus, 17(2), 96-111. https:// doi.org/10.23683/2073-6606-2019-17-2-96-111

Lisin, E., Shuvalova, D., Volkova, I., \& Strielkowski, W. (2018). Sustainable development of regional power systems and the consumption of electric energy. Sustainability, 10(4), 1111. https://doi. org/10.3390/su10041111

Mitrova, T., \& Melnikov, Y. (2019). Energy transition in Russia. Energy Transitions, 3(1), 73-80. https:// doi.org/10.1007/s41825-019-00016-8

Nathaniel, S., \& Khan, S. A. R. (2020). The nexus between urbanization, renewable energy, trade, and ecological footprint in ASEAN countries. Journal of Cleaner Production, 272, 122709. https://doi.org/10.1016/j.jclepro.2020.122709

Newbery, D., Pollitt, M.G., Ritz, R.A., \& Strielkowski, W. (2018). Market design for a high-renewables European electricity system. Renewable and Sustainable Energy Reviews, 91, 695-707. https:// doi.org/10.1016/j.rser.2018.04.025

Nowotny, J., Dodson, J., Fiechter, S., Gür, T. M., Kennedy, B., Macyk, W., \& Rahman, K. A. (2018). Towards global sustainability: Education on environmentally clean energy technologies. 
Renewable and Sustainable Energy Reviews, 81, 2541-2551. https://doi.org/10.1016/j. rser.2017.06.060

National Renewable Energy Laboratory [NREL] (2016). A Retrospective Analysis of the Benefits and Impacts of U.S. Renewable Portfolio Standards. https://www.nrel.gov/docs/fy16osti/65005.pdf

Ntanos, S., Kyriakopoulos, G., Chalikias, M., Arabatzis, G., \& Skordoulis, M. (2018). Public perceptions and willingness to pay for renewable energy: A case study from Greece. Sustainability, 10(3), 687. https://doi.org/10.3390/su10030687

Park, J., \& Kim, B. (2019). An analysis of South Korea's energy transition policy with regards to offshore wind power development. Renewable and Sustainable Energy Reviews, 109, 71-84. https:// doi.org/10.1016/j.rser.2019.04.031

Proskuryakova, L. N., \& Ermolenko, G. V. (2019). The future of Russia's renewable energy sector: Trends, scenarios and policies. Renewable Energy, 143, 1670-1686. https://doi.org/10.1016/j. renene.2019.05.096

Qazi, A., Hussain, F., Rahim, N. A., Hardaker, G., Alghazzawi, D., Shaban, K., \& Haruna, K. (2019). Towards sustainable energy: a systematic review of renewable energy sources, technologies, and public opinions. IEEE Access, 7, 63837-63851. https://doi.org/10.1109/ACCESS.2019.2906402

Rausser, G., Strielkowski, W., \& Štreimikienè, D. (2018). Smart meters and household electricity consumption: A case study in Ireland. Energy \& Environment, 29(1), 131-146. https://doi. org/10.1177/0958305X17741385

Setyowati, A. B. (2021). Mitigating inequality with emissions? Exploring energy justice and financing transitions to low carbon energy in Indonesia. Energy Research \& Social Science, 71, 101817. https://doi.org/10.1016/j.erss.2020.101817

Skytt, T., Nielsen, S. N., \& Jonsson, B. G. (2020). Global warming potential and absolute global temperature change potential from carbon dioxide and methane fluxes as indicators of regional sustainability-A case study of Jämtland, Sweden. Ecological Indicators, 110, 105831. https://doi. org/10.1016/j.ecolind.2019.105831

Suškevičs, M., Eiter, S., Martinat, S., Stober, D., Vollmer, E., de Boer, C. L., \& Buchecker, M. (2019). Regional variation in public acceptance of wind energy development in Europe: What are the roles of planning procedures and participation? Land Use Policy, 81, 311-323. https://doi.org/10.1016/j. landusepol.2018.10.032
Tagliapietra, S., Zachmann, G., Edenhofer, O., Glachant, J. M., Linares, P., \& Loeschel, A. (2019). The European union energy transition: Key priorities for the next five years. Energy Policy, 132, 950-954. https://doi.org/10.1016/j. enpol.2019.06.060

Tiba, S., \& Belaid, F. (2021). Modeling the nexus between sustainable development and renewable energy: The African perspectives. Journal of Economic Surveys, 35(1), 307-329. https://doi. org/10.1111/joes.12401

Triglobal (2020). Fossil fuels: The core of the climate change crisis. https://www.triglobalenergy.com/ climate_change

Tschopp, D., Tian, Z., Berberich, M., Fan, J., Perers, B., \& Furbo, S. (2020). Large-scale solar thermal systems in leading countries: A review and comparative study of Denmark, China, Germany and Austria. Applied Energy, 270, 114997. https:// doi.org/10.1016/j.apenergy.2020.114997

Zeballos-Roig, J. \& Wang, A. (2019). Americans really want the US to adopt renewable energy like wind and solar power, while rejecting fossil fuels like coal. Business Insider. https://www. businessinsider.com/americans-really-want-theus-adopt-renewable-energy-sources-2019-10

Zerrahn, A., Schill, W. P., \& Kemfert, C. (2018). On the economics of electrical storage for variable renewable energy sources. European Economic Review, 108, 259-279. https://doi.org/10.1016/j. euroecorev.2018.07.004

Zhang, D., Wang, J., Lin, Y., Si, Y., Huang, C., Yang, J., \& Li, W. (2017). Present situation and future prospect of renewable energy in China. Renewable and Sustainable Energy Reviews, 76, 865-871. https://doi.org/10.1016/j.rser.2017.03.023

Zlyvko, O., Lisin, E., Rogalev, N., Kurdiukova, G. (2014). Analysis of the concept of industrial technology platform development in Russia and in the EU. International Economics Letters, 3(4), 124-138. https://doi.org/10.24984/iel.2014.3.4.2

\section{Acknowledgements}

The article was prepared in accordance with the Research Plan of the Institute of Economics of the Urals Branch of the Russian Academy of Sciences. 